\title{
Preparation of Iron-Amido Complexes via Putative Fe(IV) Imido Intermediates
}

\author{
Supporting Information
}

Robie L. Lucas, Douglas R. Powell, and A. S. Borovik

Department of Chemistry

University of Kansas

Lawrence, KS 66045 


\section{General Methods}

All reagents were purchased from commercial sources and used as received, unless otherwise noted. Solvents were purified according to standard procedures. Anhydrous solvents were purchased from Aldrich. Potassium hydride (KH) as a $30 \%$ dispersion in mineral oil was filtered with a medium porosity glass frit and washed five times each with pentane and $\mathrm{Et}_{2} \mathrm{O}$. The solid $\mathrm{KH}$ was dried under vacuum and stored under an inert atmosphere. The synthesis of $p$-tolyl azide was conducted according to a procedure for preparing mesityl azide. ${ }^{1}$ The syntheses of metal complexes were conducted in a Vacuum Atmospheres, Co. drybox under an argon atmosphere. Elemental analyses were accomplished at Desert Analytics, Tucson, AZ.

\section{Preparative Methods \\ Potassium \{bis[( $N^{\prime}$-tert-butylureayl)- $N$-ethyl]-( $N^{\prime \prime}$-isopropylcarbamoylmethyl)- aminatoferrate(II) $\} \mathbf{K}\left[\mathbf{F e}^{\mathrm{II}} \mathbf{H}_{2} 2\right]$ A solution of ligand $\mathrm{H}_{5} \mathbf{2}(300 \mathrm{mg}, 0.749 \mathrm{mmol})$ dissolved in 12 $\mathrm{mL}$ of anhydrous DMA was treated with solid $\mathrm{KH}(90 \mathrm{mg}, 2.2 \mathrm{mmol})$ and stirred until gas evolution ceased. $\mathrm{Fe}(\mathrm{OAc})_{2}(130 \mathrm{mg}, 0.747 \mathrm{mmol})$ was added to the pale yellow solution, and stirring was continued for $30 \mathrm{~min}$. The amber mixture was filtered to remove KOAc $(137 \mathrm{mg}$, $93 \%$ for 2 equiv). Vapor diffusion of $\mathrm{Et}_{2} \mathrm{O}$ into the filtrate produced a pale tan solid, which was filtered, washed with $\mathrm{Et}_{2} \mathrm{O}$, and dried under vacuum to $338 \mathrm{mg}(78 \%)$. Anal. Calcd (found) for $\mathrm{K}\left[\mathrm{Fe}^{\mathrm{II}} \mathrm{H}_{2} 2\right] \cdot \mathrm{DMA}, \mathrm{C}_{23} \mathrm{H}_{46} \mathrm{FeKN}_{7} \mathrm{O}_{4}$ : C, 47.66 (47.21); H, 8.00 (7.68); N, 16.92 (16.61); FTIR $\left(\mathrm{Nujol}, \mathrm{cm}^{-1}\right) v(\mathrm{NH}) 3382, v(\mathrm{CO}) 1636,1596,1546,1521 ; \mu_{\mathrm{eff}}($ solid, $298 \mathrm{~K})=5.0 \mu_{\mathrm{B}}$.}

\section{Potassium $\left\{\left[\left(N^{\prime}\right.\right.\right.$-tert-butylureayl)- $N$-ethyl]-bis $\left(N^{\prime \prime}\right.$-isopropylcarbamoylmethyl)-} aminatoferrate(II) $\}$ K[Fe ${ }^{\text {II }} \mathbf{H 1}$ ] A solution of the ligand $\mathrm{H}_{4} \mathbf{1}(200 \mathrm{mg}, 0.559 \mathrm{mmol})$ dissolved in $8 \mathrm{~mL}$ of anhydrous DMA was treated with solid $\mathrm{KH}(67 \mathrm{mg}, 1.7 \mathrm{mmol})$ and stirred until gas evolution ceased. $\mathrm{Fe}(\mathrm{OAc})_{2}(97 \mathrm{mg}, 0.558 \mathrm{mmol})$ was added to the pale yellow suspension, and stirring was continued for $30 \mathrm{~min}$. The amber mixture was filtered to remove KOAc (108 $\mathrm{mg}$, $98 \%$ for 2 equiv). Vapor diffusion of $\mathrm{Et}_{2} \mathrm{O}$ into the filtrate produced a pale tan solid, which was filtered, washed with $\mathrm{Et}_{2} \mathrm{O}$, and dried under vacuum to $265 \mathrm{mg}(88 \%)$. Anal. Calcd (found) for $\mathrm{K}\left[\mathrm{Fe}^{\mathrm{II}} \mathrm{H1}\right] \cdot \mathrm{DMA}, \mathrm{C}_{21} \mathrm{H}_{41} \mathrm{FeKN}_{6} \mathrm{O}_{4}$ : C, 47.01 (47.22); H, 7.70 (7.40); N, 15.66 (15.40); FTIR $\left(\mathrm{Nujol}, \mathrm{cm}^{-1}\right) v(\mathrm{NH}) 3375, v(\mathrm{CO}) 1667,1643,1561,1539 ; \mu_{\mathrm{eff}}($ solid, $298 \mathrm{~K})=5.1 \mu_{\mathrm{B}}$.

Potassium \{bis[( $N^{\prime}$-tert-butylureayl $)-N$-ethyl $]$ - $\left(N^{\prime \prime}\right.$-isopropylcarbamoylmethyl $)$ aminato( $p$ tolylamido)ferrate(III) $\} \mathbf{K}$ [Fe ${ }^{\text {III }} \mathbf{H}_{2} \mathbf{2}$ (NHTol)] A solution of the ligand $\mathrm{H}_{5} \mathbf{2}$ (100 $\mathrm{mg}, 0.250$ mmol) dissolved in $4 \mathrm{~mL}$ of anhydrous DMA was treated with solid $\mathrm{KH}(30 \mathrm{mg}, 0.75 \mathrm{mmol})$ and stirred until gas evolution ceased. $\mathrm{Fe}(\mathrm{OAc})_{2}(43 \mathrm{mg}, 0.25 \mathrm{mmol})$ was added to the pale yellow solution, and stirring was continued for $30 \mathrm{~min}$. The mixture was filtered to remove KOAc, and the amber filtrate was treated with $p$-tolyl azide $(33 \mathrm{mg}, 0.25 \mathrm{mmol}$, dissolved in $\sim 1 \mathrm{~mL}$ of DMA). Gas evolution was observed from the dark black-green solution. The solution was stirred for $1 \mathrm{~h}$ and then concentrated in vacuo. The residue was treated with $1: 1 \mathrm{Et}_{2} \mathrm{O}$ /pentane to yield a dark green solid, which was filtered, washed with $\mathrm{Et}_{2} \mathrm{O}$, and dried under vacuum to 128 $\mathrm{mg}(86 \%)$. Some crystals suitable for X-ray diffraction and elemental analysis were obtained by vapor diffusion of $\mathrm{Et}_{2} \mathrm{O}$ directly into the reaction mixture containing $\mathrm{K}\left[\mathrm{Fe}^{\mathrm{IIl}} \mathrm{H}_{2} 2^{\mathrm{iPr}}(\mathrm{NHTol})\right]$. Anal Calcd (found) for $\mathrm{K}\left[\mathrm{Fe}^{\mathrm{III}} \mathrm{H}_{2} 2^{\mathrm{iPr}}(\mathrm{NHTol})\right], \mathrm{C}_{26} \mathrm{H}_{45} \mathrm{FeKN}_{7} \mathrm{O}_{3}: \mathrm{C}, 52.17$ (52.17); H, 7.58 (7.53); N, 16.38 (16.26); FTIR (Nujol, $\left.\mathrm{cm}^{-1}\right) v(\mathrm{NH}) 3331,3301, v(\mathrm{CO}) 1592,1559,1521 ; \lambda_{\max }(\mathrm{DMA}, \mathrm{nm}$ $\left.\left(\varepsilon, \mathrm{M}^{-1} \mathrm{~cm}^{-1}\right)\right) 410$ (4000), 582 (2000); X-band EPR (DMA, $\left.4 \mathrm{~K}\right) g=8.65,4.15$.

Potassium $\left\{\left[\left(N^{\prime}\right.\right.\right.$-tert-butylureayl $)-N$-ethyl $]$-bis $\left(N^{\prime \prime}\right.$-isopropylcarbamoylmethyl $)$ aminato $(p$ tolylamido)ferrate(III) $\} \mathbf{K}$ [Fe ${ }^{\mathrm{III}} \mathbf{H 1}$ (NHTol)] A solution of the ligand $\mathrm{H}_{4} \mathbf{1}(100 \mathrm{mg}, 0.280$ mmol) dissolved in $4 \mathrm{~mL}$ of anhydrous DMA was treated with solid $\mathrm{KH} \mathrm{(34} \mathrm{mg}, 0.85 \mathrm{mmol})$ and stirred until gas evolution ceased. $\mathrm{Fe}(\mathrm{OAc})_{2}(49 \mathrm{mg}, 0.28 \mathrm{mmol})$ was added to the pale yellow suspension, and stirring was continued for $30 \mathrm{~min}$. The mixture was filtered to remove KOAc, and the amber filtrate was treated with $p$-tolyl azide $(38 \mathrm{mg}, 0.29 \mathrm{mmol}$, dissolved in $\sim 1 \mathrm{~mL}$ of DMA). Gas evolution was observed from the dark black-green solution. The solution was stirred for $1 \mathrm{~h}$ and then concentrated in vacuo. The residue was treated with $1: 1 \mathrm{Et}_{2} \mathrm{O} /$ pentane to 
yield a dark green solid, which was filtered, washed with $\mathrm{Et}_{2} \mathrm{O}$, and dried under vacuum to 147 mg $(95 \%)$. FTIR (Nujol, $\left.\mathrm{cm}^{-1}\right) v(\mathrm{NH}) 3283, v(\mathrm{CO}) 1595,1558,1530 ; \lambda_{\max }\left(\mathrm{DMA}, \mathrm{nm}\left(\varepsilon, \mathrm{M}^{-1} \mathrm{~cm}^{-}\right.\right.$ $\left.\left.{ }^{1}\right)\right) 400$ (sh), 600 (3000); X-band EPR (DMA, $4 \mathrm{~K}$ ) $\mathrm{g}=8.85$, 4.15. Note that repeated attempts to obtain a satisfactory elemental analysis for this salt were unsuccessful.

\section{Treatment of $\mathrm{K}\left[\mathrm{Fe}^{\mathrm{III}} \mathrm{H1}(\mathrm{NHTol})\right]$ and $\mathrm{K}\left[\mathrm{Fe}^{\mathrm{III}} \mathrm{H}_{2} 2(\mathrm{NHTol})\right]$ with $\mathrm{H}_{2} \mathrm{O}$}

A solution of the ligand $\mathrm{H}_{4} \mathbf{1}(100 \mathrm{mg}, 0.280 \mathrm{mmol})$ dissolved in $3 \mathrm{~mL}$ of anhydrous DMA was treated with solid $\mathrm{KH}(34 \mathrm{mg}, 0.85 \mathrm{mmol})$ and stirred until gas evolution ceased. $\mathrm{Fe}(\mathrm{OAc})_{2}(49$ $\mathrm{mg}, 0.28 \mathrm{mmol}$ ) was added to the pale yellow suspension, and stirring was continued for $30 \mathrm{~min}$. The mixture was filtered to remove KOAc, and the amber filtrate was transferred to a $5.0 \mathrm{~mL}$ volumetric flask. $p$-Tolyl azide ( $37 \mathrm{mg}, 0.29 \mathrm{mmol}$, dissolved in $\sim 1 \mathrm{~mL}$ of DMA) was added, and the reaction solution was diluted to $5.0 \mathrm{~mL}$. Gas evolution was observed from the dark green solution, which was stirred for $15 \mathrm{~min}$. Two drops of the dark green solution were removed and added to a $0.005 \mathrm{~cm}$ cuvette (NSG Precision Cells, Inc.) and a visible absorbance spectrum was measured. The remaining portion of the reaction solution was treated with $\mathrm{H}_{2} \mathrm{O}$ $(5.0 \mu \mathrm{L}, 0.28 \mathrm{mmol})$, resulting in a rapid color change to dark red-orange. The solution was subsequently analyzed by UV-vis spectroscopy, giving spectral features that match that of the $\mathrm{Fe}(\mathrm{III})$ hydroxo complex, [Fe $\left.{ }^{\mathrm{III}} \mathrm{H1}(\mathrm{OH})\right]^{-}$(Figures S1 \& S2); a 95\% conversion to $\left[\mathrm{Fe}^{\mathrm{III}} \mathrm{H} 1(\mathrm{OH})\right]^{-}$ was determine by this method. An X-band EPR spectrum of the reaction mixture measured at 77 $\mathrm{K}$ also corresponds to that of $\left[\mathrm{Fe}^{\mathrm{III}} \mathrm{H1}(\mathrm{OH})\right]^{-}$prepared by independent methods (Figure $\mathrm{S} 3$ ). ${ }^{2}$ Spectral substraction of the absorbance arising from $\left[\mathrm{Fe}^{\mathrm{III}} \mathrm{H1}(\mathrm{OH})\right]^{-}$at $302 \mathrm{~nm}$ was used to calculate a yield of $60 \%$ for $p$-toluidine $\left(\lambda_{\max }\left(\mathrm{DMA}, \mathrm{nm}\left(\varepsilon, \mathrm{M}^{-1} \mathrm{~cm}^{-1}\right)\right) 302(2400)\right)$ (Figure S2). A similar protocol was used for the reaction of $\mathrm{K}\left[\mathrm{Fe}^{\mathrm{III}} \mathrm{H}_{2} 2(\mathrm{NHTol})\right]$ with $\mathrm{H}_{2} \mathrm{O}$, which produced $\mathrm{K}\left[\mathrm{Fe}^{\mathrm{III}} \mathrm{H}_{2} 2(\mathrm{OH})\right]$ and $p$-toluidine in yields of 50 and $30 \%$, respectively.

Syntheses of $\mathrm{K}\left[\mathrm{Fe}^{\mathrm{III}} \mathrm{H1}(\mathrm{NHTol})\right]$ and $\mathrm{K}\left[\mathrm{Fe}^{\mathrm{III}} \mathrm{H}_{2} 2(\mathrm{NHTol})\right]$ in the presence of $\mathrm{H}$-atom donors Preparations of $\mathrm{K}\left[\mathrm{Fe}^{\mathrm{III}} \mathrm{H1}(\mathrm{NHTol})\right]$ and $\mathrm{K}\left[\mathrm{Fe}^{\mathrm{III}} \mathrm{H}_{2} 2(\mathrm{NHTol})\right]$ done in the presence of 9,10dihydroanthracene or 1,2-diphenylhydrazine followed the procedures outlined above with the following modifications. Prior to addition of $p$-tolyl azide, the amber filtrate was treated with 0.5 equiv of 9,10-dihydroanthracene or 1,2-diphenylhydrazine. After addition of $p$-tolyl azide, the dark solution was stirred for $1 \mathrm{~h}$ and then concentrated in vacuo. The residue was treated with 1:1 $\mathrm{Et}_{2} \mathrm{O}$ /pentane and the resulting dark green solid filtered, washed with $\mathrm{Et}_{2} \mathrm{O}$, and dried under vacuum. The filtrate was concentrated to yield the organic additive and/or its products.

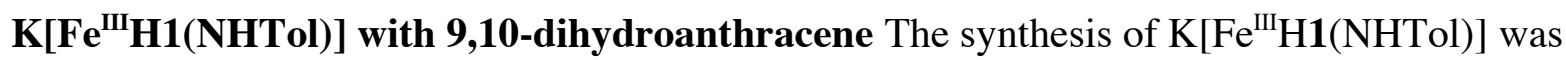
carried out in the presence of 9,10-dihydroanthracene $(25 \mathrm{mg}, 0.14 \mathrm{mmol})$ to yield $141 \mathrm{mg}$ of $\mathrm{K}\left[\mathrm{Fe}^{\mathrm{III}} \mathrm{H1}(\mathrm{NHTol})\right]$. Concentration of the $\mathrm{Et}_{2} \mathrm{O}$ /pentane filtrate gave a pale yellow solid weighing $22 \mathrm{mg}$. Analysis by ${ }^{1} \mathrm{H}$ NMR spectroscopy $\left(400 \mathrm{MHz}, \mathrm{CDCl}_{3}\right.$ ) indicated the following composition (\% yield) for the solid: anthracene (49\%), 9,9',10,10'-tetrahydro-9,9'-bianthracene (19\%), and 9,10-dihydroanthracene (19\%).

K[Fe ${ }^{\mathrm{III}} \mathrm{H}_{2}$ 2(NHTol)] with 9,10-dihydroanthracene The synthesis of $\mathrm{K}\left[\mathrm{Fe}^{\mathrm{III}} \mathrm{H}_{2}\right.$ 2(NHTol)] was carried out in the presence of 9,10-dihydroanthracene $(22 \mathrm{mg}, 0.12 \mathrm{mmol})$ to yield $131 \mathrm{mg}$ of $\mathrm{K}\left[\mathrm{Fe}^{\mathrm{III}} \mathrm{H}_{2} 2(\mathrm{NHTol})\right]$. Concentration of the $\mathrm{Et}_{2} \mathrm{O}$ /pentane filtrate gave a pale yellow solid weighing $21 \mathrm{mg}$. Analysis by ${ }^{1} \mathrm{H} \mathrm{NMR}$ spectroscopy $\left(400 \mathrm{MHz}, \mathrm{CDCl}_{3}\right)$ indicated the following composition (\% yield) for the solid: 9,10-dihydroanthracene (73\%), anthracene (14\%), and 9,9',10,10'-tetrahydro-9,9'-bianthracene $(8 \%)$.

K[Fe $\left.{ }^{\mathrm{III}} \mathrm{H1}(\mathrm{NHTol})\right]$ with 1,2-diphenylhydrazine The synthesis of $\mathrm{K}\left[\mathrm{Fe}^{\mathrm{III}} \mathrm{H1}\right.$ (NHTol)] was carried out in the presence of 1,2-diphenylhydrazine $(25 \mathrm{mg}, 0.14 \mathrm{mmol})$ to yield $143 \mathrm{mg}$ of $\mathrm{K}\left[\mathrm{Fe}^{\mathrm{III}} \mathrm{H1}(\mathrm{NHTol})\right]$. Concentration of the $\mathrm{Et}_{2} \mathrm{O} /$ pentane filtrate gave $22 \mathrm{mg}$ of orange solid. Analysis by ${ }^{1} \mathrm{H}$ NMR spectroscopy $\left(400 \mathrm{MHz}, \mathrm{CDCl}_{3}\right)$ indicated the solid was azobenzene $(88 \%)$. 
K[Fe ${ }^{\text {III }} \mathbf{H}_{2}$ 2(NHTol)] with 1,2-diphenylhydrazine The synthesis of $\mathrm{K}\left[\mathrm{Fe}^{\mathrm{III}} \mathrm{H}_{2}\right.$ 2(NHTol)] was carried out in the presence of 1,2-diphenylhydrazine (23 $\mathrm{mg}, 0.12 \mathrm{mmol}$ ) to yield $135 \mathrm{mg}$ of $\mathrm{K}\left[\mathrm{Fe}^{\mathrm{III}} \mathrm{H}_{2} 2(\mathrm{NHTol})\right]$. Concentration of the $\mathrm{Et}_{2} \mathrm{O} /$ pentane filtrate gave $21 \mathrm{mg}$ of orange solid. Analysis by ${ }^{1} \mathrm{H}$ NMR spectroscopy $\left(400 \mathrm{MHz}, \mathrm{CDCl}_{3}\right)$ indicated the solid was azobenzene $(91 \%)$.

\section{Physical Methods}

NMR spectra were recorded on a Bruker Avance $400 \mathrm{MHz}$ spectrometer equipped with a Silicon Graphics workstation. FTIR spectra were collected on a Mattson Genesis series FTIR instrument with values reported in wavenumbers. Perpendicular-mode X-band EPR spectra were collected using a Bruker EMX spectrometer equipped with an ER041XG microwave bridge. Spectra for EPR samples were collected using the following spectrometer settings: attenuation $=25 \mathrm{~dB}$, microwave power $=0.638 \mathrm{~mW}$, frequency $=9.47 \mathrm{GHz}$, sweep width $=5000 \mathrm{G}$, modulation amplitude $=10.02 \mathrm{G}$, gain $=1.00 \times 10^{3}$, conversion time $=81.920 \mathrm{~ms}$, time constant $=655.36$ $\mathrm{ms}$, and resolution $=1024$ points. Low-temperature $(4 \mathrm{~K})$ spectra were obtained using an Oxford Instrument liquid He quartz cryostat.

\section{Crystallographic Methods}

Intensity data for this compound were collected using a Bruker APEX ccd area detector ${ }^{3}$ using graphite-monochromated Mo K $\alpha$ radiation $(\lambda=0.71073 \AA)$. The sample was cooled to $100(2)$ $\mathrm{K}$. The intensity data were measured as a series of $\omega$ oscillation frames each of $0.3^{\circ}$ for $60 \mathrm{sec} /$ frame. Coverage of unique data was $99.7 \%$ complete to 26.00 degrees in $\theta$. Cell parameters were determined from a non-linear least squares fit of 2586 peaks in the range $2.25<\theta<22.90^{\circ}$. A total of 13829 data were measured in the range $2.09<\theta<26.37^{\circ}$. The data were corrected for absorption by the semi-empirical method ${ }^{4}$ giving minimum and maximum transmission factors of 0.8745 and 0.9870 . The data were merged to form a set of 6329 independent data with R(int) $=0.0392$.

$\mathbf{K}\left[\mathrm{Fe}^{\mathrm{III}} \mathbf{H}_{2} 2\right.$ (NHTol)] crystallized in the triclinic space group $P$, which was determined by statistical tests and verified by subsequent refinement. The structure was solved by direct methods and refined by full-matrix least-squares methods on $F^{2}$. Non-hydrogen atoms were refined with anisotropic displacement parameters. Hydrogen atom positions on carbons were initially determined by geometry and refined by a riding model. Hydrogens bound to nitrogens were located on a difference map and refined independently. For hydrogens bonded to carbons, hydrogen atom displacement parameters were set to 1.2 (1.5 for methyl) times the displacement parameters of the bonded atoms. A total of 355 parameters were refined against 6329 data to give $\mathrm{wR}\left(F^{2}\right)=0.1904$ and $\mathrm{S}=1.041$ for weights of $\mathrm{w}=1 /\left[\sigma^{2}\left(F^{2}\right)+(0.1000 \mathrm{P})^{2}+1.0000 \mathrm{P}\right]$, where $\mathrm{P}=\left[F_{\mathrm{o}}^{2}+2 F_{\mathrm{c}}^{2}\right] / 3$. The final $\mathrm{R}(F)$ was 0.0642 for the 4115 observed, $[F>4 \sigma(F)]$, data. The largest shift/s.u. was 0.001 in the final refinement cycle. The final difference map had maxima and minima of 1.123 and $-0.557 \mathrm{e} / \AA^{3}$, respectively. 


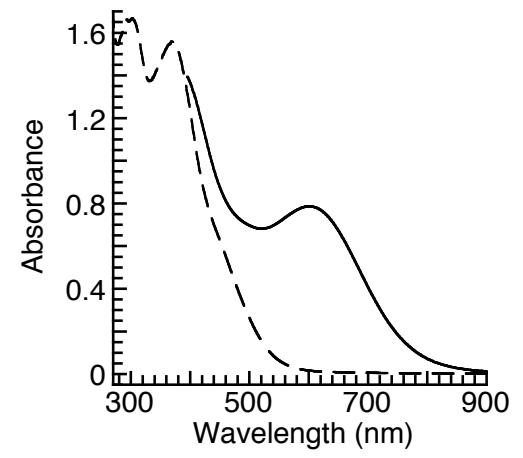

Figure S1. Visible absorbance spectra for $\left[\mathrm{Fe}^{\mathrm{III}} \mathrm{H1}(\mathrm{NHTol})\right]^{-}$in DMA ( -$)$and after treating with 1 equiv of $\mathrm{H}_{2} \mathrm{O}$ (---).

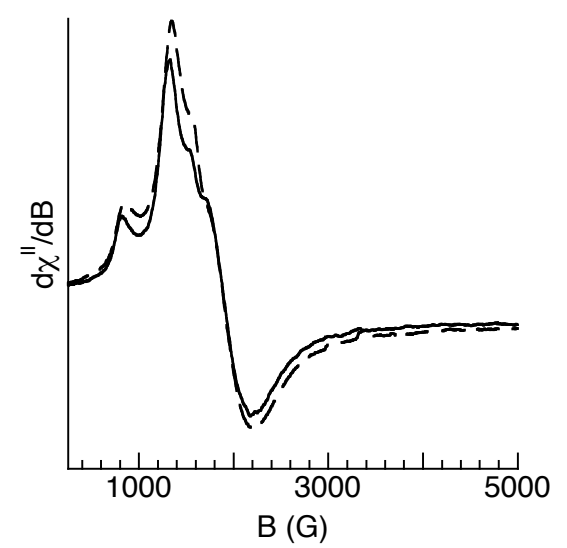

Figure S3. X-band EPR spectra measured at $77 \mathrm{~K}$ for the reaction mixture of $\left[\mathrm{Fe}^{\mathrm{III}} \mathrm{H1}(\mathrm{NHTol})\right]^{-}$after treatment with 1 equiv of $\mathrm{H}_{2} \mathrm{O}$ in DMA $(-)$ and $\left[\mathrm{Fe}^{\mathrm{III}} \mathrm{H1}(\mathrm{OH})\right]^{-}(--)$in DMA.

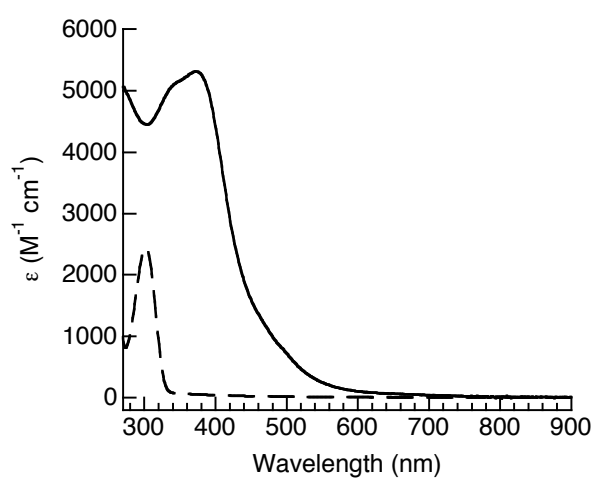

Figure S2. Visible absorbance spectra of $\left[\mathrm{Fe}^{\mathrm{III}} \mathrm{H} \mathbf{1}(\mathrm{OH})\right]^{-}(-)$and $p$-toluidine (---) measured in DMA.

\section{References}

(1) Murata, S.; Abe, S.; Tomioka, H. J. Org. Chem. 1997, 62, 3055-3061.

(2) $\left[\mathrm{Fe}^{\mathrm{III}} \mathrm{H1}(\mathrm{OH})\right]^{-}$and $\left[\mathrm{Fe}^{\mathrm{III}} \mathrm{H}_{2} 2(\mathrm{OH})\right]^{-}$have been prepared by independent methods from either trimethylamine $N$-oxide or dioxygen and are fully characterized. Full details will be described in a subsequent manuscript.

(3) (a) Data Collection: SMART Software Reference Manual; Bruker-AXS: Madison, WI, 1994.

(b) Data Reduction: SAINT Software Reference Manual; Bruker-AXS: Madison, WI, 1995.

(4) Sheldrick, G. M. SADABS: Program for Empirical Absorption Correction of Area Detector Data; University of Göttingen, Germany, 2000.

(5) (a) Sheldrick, G. M. SHELXTL Version5 Reference Manual; Bruker-AXS: Madison, WI, 1994. (b) International Tables for Crystallography; Kluwer Academic Publishers: Norwell, MA, 1995; Vol C., Tables 6.1.1.4, 4.2.6.8, and 4.2.4.2. 